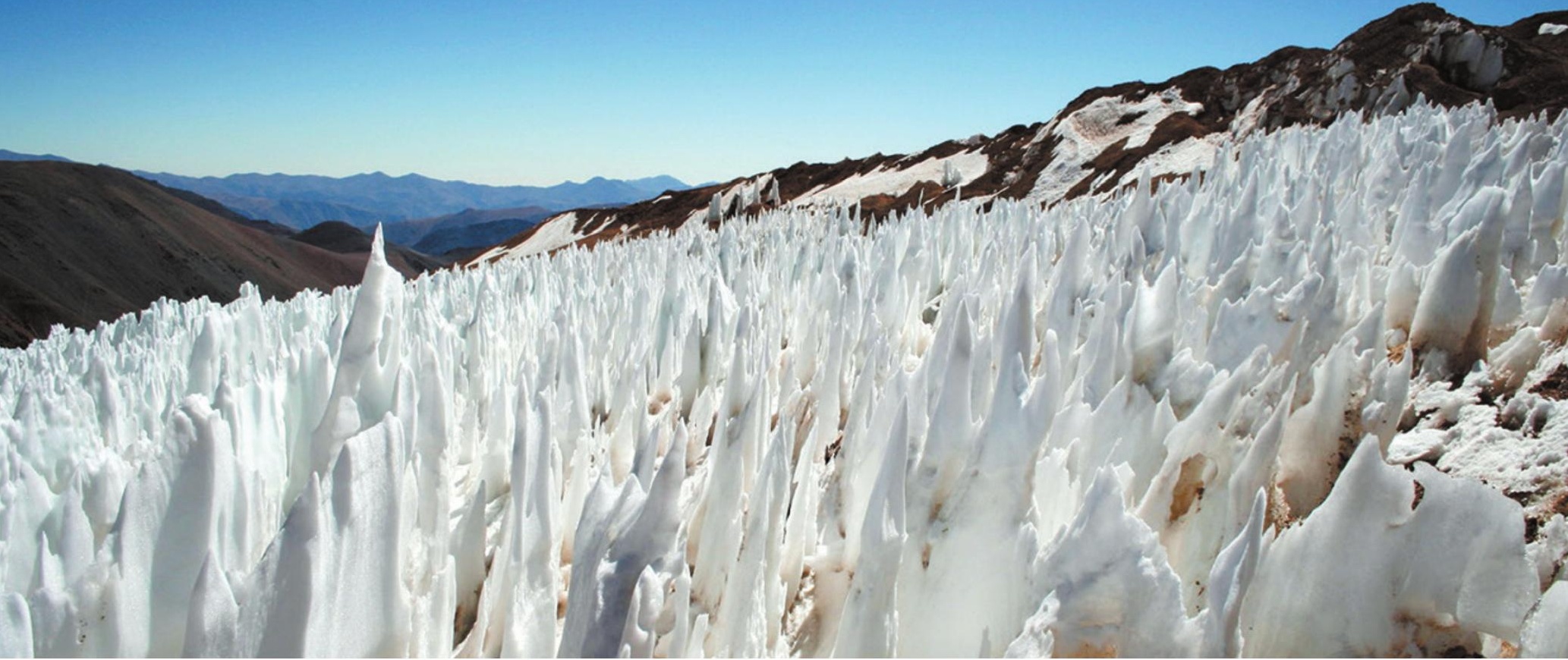

The El Toro Il glacier on the Chile-Argentina border, near the Pascua Lama gold mine.

ENVIRONMENTAL POLICY

\title{
Legislation left out in the cold
}

\author{
Mark Carey examines the cautionary tale of Argentina's struggle to pass the \\ world's first glacier-protection law.
}

\section{$\mathrm{T}$} he human-driven 'big melt' in the cryosphere is a major concern, with issues such as reduced glacier runoff riddling headlines. Glaciers are crucial, scientifically, socially and economically: they affect sea level, feed rivers, yield some of the world's most precise climate data in ice cores, and draw tourism to icy landscapes. But as Jorge Daniel Taillant explains in Glaciers, few people are actually doing anything about the melt - except in Argentina, where in 2010 authorities implemented what he refers to as the world's first glacier-protection law.

The rocky path towards creation of that law started in 2006, when Argentina's secretary of the environment (and Taillant's wife) Romina Picolotti learned that the Barrick Gold mining company of Toronto, Canada, had dynamited three glaciers at its Pascua Lama mine on the Chile-Argentina border to access a gold seam. What followed was a struggle to create and implement a national law to save glaciers from the damaging impacts of mining, hydrocarbon exploration and industrial development. Taillant $\checkmark$ NATURE.COM in culture, see:

nature.com/

booksandarts
For more on science refers to the quest as cryoactivism, a term coined by French glaciologist Bernard Francou.

Glaciers is a blow-by-blow account of progress towards the enactment and implementation of the law. It details both Picolotti's glacier-saving activism and Taillant's own, through the Center for Human Rights and Environment (CEDHA) - a nongovernmental organization in Cordoba, Argentina, of which he is executive director.

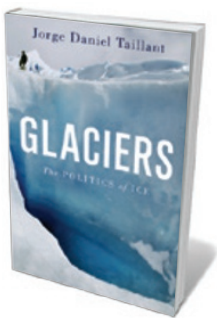

Glaciers: The Politics of Ice JORGE DANIEL

TAILLANT

Oxford Univ. Press USA: 2015.

As a result, the book

is largely an autobiographical account. But it offers discussion of glacier features, rock glaciers and the periglacial system, brief accounts of glacier shrinkage around the world and a chapter that includes an assortment of vignettes about human-glacier dynamics from the creation of artificial glaciers in India to the 5,300-year-old mummy Ötzi, found in ice on the Austrian-Italian border.

Taillant notes that in 2008, Picolotti ushered the Minimum Standards Law for the Protection of Glaciers and the Periglacial Environment through Argentina's Congress with a unanimous vote in favour. The law sought to conserve glacial and periglacial environments as hydrological resources, appeasing environmentalists and antimining activists who sought to save such resources for agriculture and potable water. But two weeks later, President Cristina Fernández de Kirchner vetoed the law.

Taillant speculates that "it is more than likely" that Barrick Gold president Peter Munk intervened. He bases his argument on three things: the law directly threatened billions of dollars of gold buried at Pascua Lama; Munk had "a one-on-one relationship with the Kirchners"; and Argentina's mining provinces (which might otherwise have been suspected of providing the opposition) remained supportive of the law. In 2010, several provinces enacted their own glacier-protection laws; Santa Cruz was "the first jurisdiction in the world" to adopt one. Later that year, environmental activists got support from Senator Daniel Filmus and Congressional Deputy Miguel Bonasso to push a new national glacier-protection law through the Congress: this one defined glaciers as "strategic freshwater reserves" for Argentina. Kirchner approved it.

Taillant shows how enforcement of this law has had a bumpy ride. A national glacier inventory, crucial for identifying what needs protection, was mandated but remains unfinished. In 2010, in an effort to stand up to what he sees as mining-company power, 
Taillant enrolled in a one-week glaciology course. He has since worked through CEDHA to identify glaciers using satellite imagery, and to conduct observations in mining regions. He strives to pinpoint glacier 'hotspots', where protection is lacking or mining claims or roads are a threat. Lowerlevel Argentinian courts have twice ruled to uphold the glacier law.

Although it is informative on Argentina's environmental policy, Taillant's book misses the mark on some of the science - especially when compared to glaciology texts or books such as Mariana Gosnell's Ice (Univ. Chicago Press, 2007) and Mark Bowen's Thin Ice (Henry Holt, 2005). When it discusses glaciers as water sources, the book does not precisely quantify the contributions of glacier runoff to downstream water supplies. It suggests that all glacial ice translates directly into water for human consumption, which exaggerates glacial input and runs contrary to studies that reveal that glaciers contribute up to $30 \%$ of downstream water in Peru and 27\% in Bolivia, with sharp variations between dry and wet seasons. Nor does Taillant explain how groundwater, precipitation and land-use practices influence hydrology in glacierized watersheds. The book's claim that perennial snow is the same thing as a glacier, and reference to "glaciers" that are only 3 metres thick (and therefore lack internal ice deformation, a defining characteristic) will raise eyebrows among glaciologists. When referring to diminishing glacier runoff in the Himalayas, the book cites treehugger.com - and at other points, Wikipedia.

Taillant argues that glacial contributions to hydrology are the basis for the glacier-protection law. But we do not know what proportion of Argentina's downstream water they supply, during what season, or how that varies from glacier to sea. Without quantifying or fully explaining these contributions, the law and this book seem motivated by cultural values about endangered ice, rather than by scientific data. This tension is one that I have analysed before and that has been tackled by authors including Julie Cruikshank in Do Glaciers Listen? (Univ. British Columbia Press, 2005) and Eric Wilson in The Spiritual History of Ice (Palgrave Macmillan, 2009). Environmental laws, including those on glacier protection, evolve in the fraught national-to-global context of competing agendas, from the corporate to the governmental to that of environmental activists. As such, they frequently speak for, rather than with, local residents who, as Taillant himself argues, have a human right to glaciers.

Mark Carey is an associate professor of history in the Clark Honors College at the University of Oregon in Eugene, and author of In the Shadow of Melting Glaciers. e-mail:carey@uoregon.edu

\section{Books in brief}

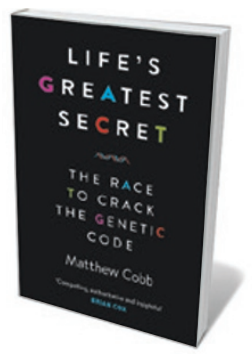

Life's Greatest Secret: The Race to Crack the Genetic Code

Matthew Cobb PROFILE (2015)

James Watson's The Double Helix (Athenaeum, 1968) and Horace Judson's The Eighth Day of Creation (Touchstone, 1979) are classics on the 1953 discovery of DNA's structure, and the research that consolidated it. Zoologist Matthew Cobb richly recontexualizes the tale, tracing the interplay between biology, chemistry and physics that led to and amplified the breakthrough. This is a lucid explication of the science and the stories of key players, from X-ray crystallographer Rosalind Franklin and physicist Max Delbrück to Oswald Avery, who linked DNA to genes, and information theorist Claude Shannon.

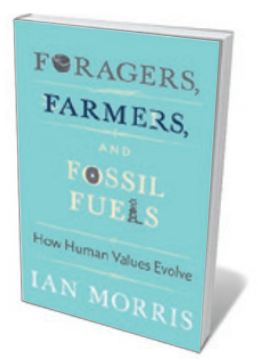

Foragers, Farmers, and Fossil Fuels: How Human Values Evolve lan Morris PRINCETON UNIVERSITY PRESS (2015)

Energy capture - as a "brute material force" — shapes human values, argues archaeologist lan Morris in this global-scale study of cultural variation. Looking at modes of capture from hunting and gathering to the agricultural and industrial revolutions, he avers that each determines population size, social organization and values. Now, writes Morris, our globalized society faces a "Malthusian collapse" - and a lurch towards new values - driven by nuclear weapons, climate change and digitization. With contributions from writer Margaret Atwood, sinologist Jonathan Spence and others.

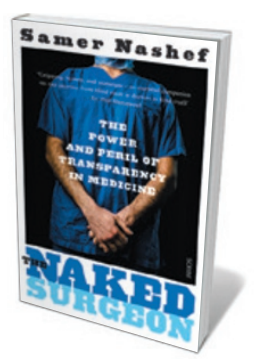

\section{The Naked Surgeon}

Samer Nashef SCRIBE (2015)

UK consultant cardiac surgeon Samer Nashef joins the swelling ranks of medics who have penned frank inside stories. Piquant detail abounds: operating on the heart, for instance, involves "twisting it, pressing on it, and sometimes turning it upside down". But it is Nashef's long study of risk that injects nuance. It began in 1977, when he discovered that arterial surgeons were responsible for the worst outcomes in a sample of abdominal aortic aneurysm operations. Such failures have, he shows, driven quality measurement in medicine, including his own heart-surgery risk model, EuroSCORE.

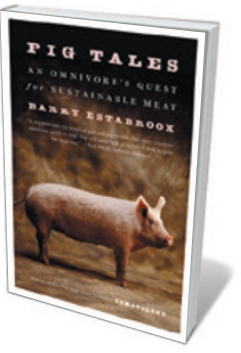

Pig Tales: An Omnivore's Quest for Sustainable Meat

Barry Estabrook W. W. NORTON (2015)

Cheap pork should give us pause, writer Barry Estabrook argues in this cogent, level-headed investigation of the pig as raised and researched. The animal is one of the most intelligent ever domesticated, yet some 97 million in the United States are packed into reeking factory farms, with widespread 'crating' of pregnant sows. Yet as Estabrook reveals, humane, state-of-the-art husbandry is within our grasp and ultimately more profitable. He introduces an impressive group of animal scientists, farmers and pigs, from computer-savvy lab piglets to havoc-wreaking feral hogs.

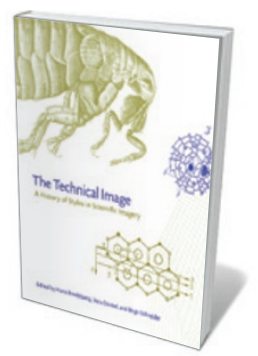

The Technical Image: A History of Styles in Scientific Imagery Editors Horst Bredekamp, Vera Dünkel and Birgit Schneider UNIVERSITY OF CHICAGO PRESS (2015)

This multidisciplinary study trains an art historian's eye on historical scientific imagery. Editors Horst Bredekamp, Vera Dünkel and Birgit Schneider draw on research from the Humboldt University of Berlin and a range of haunting images. They show that an iconic 1896 radiograph of a hand by X-ray discoverer Wilhelm Röntgen prompted both rhapsodies over a "photography of the invisible" and frustration among medics struggling to use such images for diagnosis. Barbara Kiser 